\title{
Commercial Sponge Fishery Impacts on the Population Dynamics of Sponges in the Florida Keys, FL (USA)
}

\author{
Mark J. Butler IV ${ }^{1}$, Donald C. Behringer ${ }^{2,3}$ and Marla M. Valentine ${ }^{1}$ \\ ${ }^{1}$ Department of Biological Sciences, Old Dominion University, Norfolk, VA 23529 USA, mbutler@odu.edu, \\ mvale017@odu.edu \\ ${ }^{2}$ School of Forest Resources and Conservation, Program in Fisheries and Aquatic Sciences, University of Florida, \\ Gainesville, FL 32653 USA, behringer@ufl.edu \\ ${ }^{3}$ Emerging Pathogens Institute, University of Florida, Gainesville, FL 32608
}

\section{Abstract}

For more than 100 years, the Florida Keys (USA) have supported a commercial sponge fishery but there is little information about the small artisanal fishery that now exists, which is nonetheless controversial because of concerns about the ecological consequences of sponge harvest. We estimated the harvest of commercial sponges and bycatch (sublegal or noncommercial species), as well as the mortality, growth, and reproduction of commercial sponge species. In heavily fished areas, $\sim 33 \%$ of the legal-sized sponges, $\sim 3 \%$ of the sublegal sponges, and virtually none of the non-commercial species were harvested. Approximately $40 \%$ of our study area was never fished during the four month long peak in the fishing season. Self-reporting of harvest by fishers who participated in our study closely matched our fishery-independent estimates. Natural mortality of sublegal-sized sponges was $\sim 7 \%$ of the population/yr, with little difference among species. Discarded "roller" sponges grew at rates comparable to attached sponges and many reattached to the seafloor within $18 \mathrm{mos}$, although rates of reattachment varied among species. Growth also differed among species and sampling periods (mean $=3 \mathrm{~cm}$ $\mathrm{dia} / \mathrm{yr}$ ), and reproductive effort was positively related to sponge size in some species, but not others. Given the careful targeting of commercial sponge species and sizes by fishers and the small fraction of the sponge community that is commercially valuable, harvest is estimated to have minimal impact on the diverse assemblage of sponges in the region.

29 Key words: growth, reproduction, sponge, artisanal, Florida, fishery

30 Corresponding Author:

31 Mark Butler, Department of Biological Sciences, Old Dominion University, Norfolk, VA 23529 


\section{Introduction}

Regulation and monitoring of marine fisheries is largely focused on economically valuable taxa (Newell, 1988; Hughes, 1994; Jackson et al., 2001), whereas management of organisms of less commercial value is often minimal despite their potential ecological importance (Karr, 1992; Brito, 2008). The sponge assemblages that support an artisanal fishery in the Florida Keys, Florida (USA) are one such example. Approximately 60 species of sponge dominate the sessile animal biomass of shallow $(<3 \mathrm{~m})$ hard-bottom communities in the Florida Keys, but only five species are of commercial value (Torres et al., 2006; Stevely et al., 2010; 2011). The region's sponge fishery began in the mid 1800's (Rathbun, 1867; Storr, 1964) and annual landings peaked at $\sim 270,000 \mathrm{~kg}(\sim 8.6$ million sponges) prior to World War II. However, the cumulative impacts of sponge die-offs, exploitation, and the introduction of artificial sponges in the 1950's doomed the fishery (Storr, 1964; Butler et al., 1995; Witzell, 1999; Stevely et al., 2008). Today, only a small, artisanal sponge fishery persists in the Florida Keys, with landings of about $5 \%$ of their peak a century earlier. Nevertheless, the current fishery is controversial because of concerns about the potentially negative impacts of sponge harvest on the functioning of the Florida Keys ecosystem.

Sponges are a common and striking component of the benthic hard-bottom communities in Florida Bay and the Gulf-side waters north of the Florida Keys where the majority of South Florida's commercial sponges occur. Mean sponge abundance exceeds 80,000/ha (Torres et al., 2006) in the region where some species, such as the Loggerhead Sponge (Spheciospongia vesparium), can exceed $1 \mathrm{~m}$ in diameter and significantly increase structural complexity of the habitat. A variety of fish and invertebrate species targeted by commercial and recreational fisheries shelter or feed in sponge-dominated hard-bottom habitat, including: bonefish (Albula vulpes), tarpon (Megalops atlanticus), Caribbean spiny lobster (Panulirus argus), stone crabs (Menippe mercenaria), Red grouper (Epinephelus morio). At least one group of animals - the eusocial snapping shrimp (Synalpheus spp.) - are obligate dwellers within some species of large sponges (Duffy, 2002).

Beyond their importance to the structural complexity of hard-bottom areas, the ecosystem services provided by sponges are many (Bell, 2008). Sponges are major contributors to the benthic pelagic coupling of energy and nutrients in Florida Bay (Behringer and Butler, 2006), are efficient filter feeders of picoplankton, and were once so numerous in the Florida Keys that their recent decline may account for a surge in phytoplankton blooms (Lynch and Phlips, 2000; Peterson et al., 2006; Wall et al., 2012). Various biogeochemical nitrogen pathways exist within sponges, including nitrification (Diaz and Ward, 1997), and nitrogen fixation by high microbial abundance (HMA) sponges that contain symbiotic cyanobacteria (Southwell, 2008; Fiore et al., 2013; Slatterly et al., 2013). These HMA species dominate sponge communities in the shallow, sponge fishing grounds of the Florida Keys.

Despite the ecological importance of shallow-water tropical sponges, little is known about their biology or the effects of the fishery on their demographics (but see Cropper and DiResta, 1999). Some sponges in the Florida Keys are reproductive year-round, but others probably reproduce only during the summer (Kaye and Reiswig, 1991a). Fecundity is thought to be related to sponge volume (Storr, 1964), but for most species surprisingly little is known about size at maturity, growth, or fecundity - information of obvious importance for sustainable management.

The sponge fishery itself is an anachronism and loosely regulated. Current sponge fishing regulations in the Florida Keys include: a prohibition on harvest by diving (spongers stand in boats and use long poles with hooks to pull sponges from the seafloor), a minimum legal size 
limit of 5 in $(12.8 \mathrm{~cm})$ diameter, a recreational harvest limit of 10 sponges per person per day, and closed areas within state and federal sanctuaries. However, rates of natural and fishing mortality are unknown for most sponge species (Cropper and DiResta, 1999), as is the effect of fishing on undersized or undesirable species (i.e., bycatch). Sponge fishermen are required to return to the water any non-commercial or sublegal sponges that they mistakenly harvest, but the fate of these unattached "rollers" is unknown. Therefore, we conducted several field studies to determine the harvest efficiency and sponge bycatch associated with commercial sponge fishing. We also estimated the growth, natural mortality, and fecundity of the most common commercial sponge species in the Florida Keys, and determined whether sponge bycatch returned to the sea survive, grow, and reattach to the seafloor.

\section{Methods}

\subsection{Fishery effects}

We estimated fishing effort, harvest efficiency, and bycatch in a study conducted in collaboration with local fishers within four regions of the Florida Keys where sponge harvesting is common: Duck Key (Middle Keys), Waltz Key (Lower Keys), Boca Chica Key (Lower Keys), and in the Lakes region west of Key West (Fig. 1). In each of these four regions, twelve study sites were haphazardly selected and designated into three groups: (a) four sites were marked with research buoys and on each we measured and monitored sponges, (b) four sites were unmarked by buoys and unknown to fishermen, but on which we still measured and monitored sponges, and (c) four sites were marked with buoys, but not studied and thus served as "decoy" sites (total $=48$ sites; 32 sponge monitoring sites and 16 unmonitored decoy sites). Fishers did not know whether any particular site contained legal-sized, commercial sponges or which sites we monitored.

Within each of the 32 study sites that we monitored (each $\sim 110 \mathrm{~m}^{2} ; 12 \mathrm{~m}$ diameter), divers mapped the position of and measured (height and diameter) every commercial and noncommercial sponge $\geq 6 \mathrm{~cm}$ diameter. We monitored four commercially valuable sponge species that were present on our sites (wool sponge, Hippospongia lachne; yellow sponge, Spongia barbara; glove sponge, Spongia graminea; grass sponge, Spongia cheris) and a few other large species of no commercial value (stinker sponge, Ircinia strobilina; loggerhead sponge, Spheciospongia vesparium; cake sponge, Aaptos sp.; green sponge, Haliclona melandocia). Species with morphologies (e.g., tubular, vase-like, or small species) or colors (e.g., the orange fire sponge, Tedania ignis) obviously different from commercial species and thus unlikely to be harvested by mistake by fishers were not monitored.

Sponges were first mapped in June 2003 and the sites revisited in August and October 2003 when each mapped sponge was again measured, if present. Our study period corresponded with the primary season when fishers harvest sponges because wind speeds are often low, surface waves are minimal, and sponges thus most easily seen and harvested. Regulations in the Florida Keys restrict sponge harvesting to traditional methods that have been used in the region for over a century. Fishers stand aboard canoes or small skiffs $(<4 \mathrm{~m}$ in length), peer into the water to locate sponges, and then strip sponges from the seafloor with specialized hooks attached to $3 \mathrm{~m}$ long poles. These gear restrictions limit the harvest of sponges to periods of low wind speeds (generally $<10 \mathrm{kts}$ ) and to depths of $<2.5 \mathrm{~m}$ (limited by the length of the pole hooks employed).

Using our diver-based mapping data, we estimated the harvest efficiency of sponge fishers as the percentage of legal-sized commercial sponges removed from our 32 monitored sites per month. Bycatch was estimated in three ways: (1) the percentage of undersized commercial sponges removed per site/mo, (2) the percentage of non-commercial sponges removed per 
site/mo, and (3) the number of commercial and non-commercial sponge "rollers" found on each site/mo.

The fishermen who worked in our study areas also agreed to keep daily logbooks of their fishing activities whenever they fished near our sites, which were clearly marked with research buoys. Their logbook data included: hours fished per day; number of sponges harvested by species and size categories that are used in the fishery ( small $=12-15 \mathrm{~cm}$ dia, medium $=15-25 \mathrm{~cm}$ dia, large $>25 \mathrm{~cm}$ dia); number of sublegal-sized commercial sponges harvested and released; number of non-commercial sponges harvested and released; and number of other sponge fishing vessels observed while in the fishing area. We also used these fishery-dependent data to estimate fishing effort (number of fishing $\mathrm{d} / \mathrm{mo}$, number of fishing $\mathrm{hrs} / \mathrm{d}$ ), catch per unit effort (number of sponges harvested/d), and bycatch (number of sublegal sponges harvested/day, number of noncommercial sponges harvested/d).

\subsection{Growth, natural mortality, and reproduction}

We used data from 124 commercial sponges of four species (i.e., wool sponge, yellow sponge, glove sponge, grass sponge) that were tagged and measured by divers on five haphazardly selected sites in the Florida Keys in areas where sponge fishermen were not active during three sampling events in 2003 (March, July, October). Growth of sponges was estimated from repeated measurements of the diameter and height of the sponges that were tagged with numbered aluminum tags and whose position on each site we had mapped. We tested for differences in growth among species and sampling periods using a 2-factor, repeated measures ANOVA.

Natural mortality was estimated as the number of tagged sponges that were missing from those five sites on successive sampling periods. Attributing sponge mortality to natural causes as opposed to fishing was based on our interviews with local fishermen and observations that sponge fishers were absent at those sites, which is admittedly a subjective assessment of fishing activity. Therefore, we assumed that the sites had been fished (and thus omitted from this analysis) if one of two conditions existed: (a) legal-sized commercial sponges were missing from the site whereas other species and sub-legal commercial sponges remained, or (b) if "roller" sponges were present on the site (i.e., sponges that were erroneously harvested then returned to the sea).

To determine species-specific patterns in reproductive activity and size-specific fecundity, we used an apple corer to remove a small cylinder $\left(\sim 5 \mathrm{~mm}^{3}\right)$ of sponge endosomal tissue from untagged sponges on the same five study sites during the July 2003 sample period. We sampled a range of sizes of the four commercial sponge species: wool $(n=32)$, yellow $(n=32)$, glove $(n$ $=25)$ and grass $(n=16)$. We sampled during the summer (July) to maximize the probability that sponges would be in a reproductive state when sampled because previous studies indicate that all of the commercial sponge species we studied are reproductive during the summer (Kaye and Reiswig, 1991a,b).

We processed the sponge tissue samples for histological determination of the presence and density of reproductive structures (spermatic cysts, oocytes) using methods developed and described in detail in Kaye and Reiswig (1991a). In brief, tissue samples collected in the field were immediately fixed in a $2.5 \%$ glutaraldehyde in sterile seawater solution. In the laboratory, tissue samples were rinsed in fresh fixative and then sterile seawater, dehydrated in an alcohol series, cleared in xylene, and then embedded in paraffin using standard methods for preparation of tissues for light microscopy. Paraffin blocks containing the sponge tissue were then serially sectioned into $10 \mu \mathrm{m}$ slices, mounted on glass slides, and stained with hematoxylin-eosin. Using 
light microscopy and an image analysis system (SigmaScan Pro, Jandel Scientific Products), we then assessed each sponge tissue sample for the presence of reproductive structures (i.e., spermatic cysts or oocytes) referred to as "gametocytes". Four image sub-samples per slide were chosen haphazardly if gametocytes were present, we used the image analysis software to calculate the total area of each subsample and the area of any gametocytes visible in the sample. From those measures, we estimated the total density of gametocytes in the tissue sample as well as the percentage of the tissue sample composed of gametocytes. These two estimates of "relative fecundity" are useful for comparison of reproductive output among sponge species and size classes, which we tested in a 2-way model I ANOVA.

\subsection{Sponge reattachment experiment}

We conducted an experiment using tethered sponges to determine whether unattached roller sponges reattach to the seafloor, and whether they suffer lower growth or higher mortality while unattached. Divers cut commercial sponges of three species (i.e., wool, yellow, glove; $n=20$ sponges per species) from the seafloor, measured them (diameter, height), tagged them with individually labeled aluminum tags, and tethered them to the bottom at sites that differed in sediment depth (mean sediment depths of two types of sites: $4 \mathrm{~cm}$ versus $2 \mathrm{~cm}$ ). Our experimental "roller" sponges were tethered by running a loop of $7 \mathrm{~kg}$ test monofilament through the center of the sponge with a needle and tying the opposite end of the $0.5 \mathrm{~m}$ long tether to a galvanized steel spike driven into the bedrock beneath the sand. Each sponge was measured approximately every three months thereafter for 18 mos to determine if they had reattached to the seafloor and to estimate their growth based on changes in size (height, diameter). The growth of unattached roller sponges was compared to that of attached natural sponges (estimated from sponges surveyed for growth and natural mortality as described above) for each species using a 2-way model I ANOVA.

\section{Results}

\subsection{Fishery effects}

We measured a total of 702 sponges on the 32 fishery study sites; 462 sponges were of legal size ( $>12.8 \mathrm{~cm}$ dia; 394 commercial species and 68 non-commercial species) and the remainder $(n=240)$ were sublegal commercial species. We did not map or measure sublegal noncommercial sponges. Despite their moniker, the unattached "roller" sponges that we observed during the fishery study actually moved very little. On average, rollers moved about $0.9 \mathrm{~m}$ (sd: $1.1 \mathrm{~m} ; \mathrm{N}=45$ ) during our four-month long study. Based on observations of missing commercial sponges, the presence of rollers, and the reported activities of fishermen, we estimated that harvesting took place on approximately $60 \%$ of our study sites during the four-month study that corresponded to the peak harvest period. On sites that had obviously been fished, 33\% of the legal-sized commercial sponges were missing after the four-month period, yielding an estimated rate of harvest (i.e., proportion of legal-sized commercial species harvested per study area per month) of $8.3 \%$ per month with little difference among the three species present on the study sites (range: $7 \%-9.5 \%$ per mo; Fig. 2); grass sponges did not occur on these study sites.

Bycatch of sublegal commercial sponges and non-commercial sponges of legal size was minimal. By subtracting the loss of these types of sponges on unfished sites (i.e., natural mortality) from their loss on fished sites (i.e., natural + fishing mortality), we estimate that sublegal commercial sponges were removed at a rate of 3.5\% per mo and large, non-commercial sponges were removed at a similar rate of $4.3 \%$ per mo. Sublegal-sized wool sponges (the most valuable species) were erroneously harvested the most frequently, but monthly rates of removal 
were low for all three commercial species (range: 2\% - 4.2\%). Legal-sized cake sponges (Aaptos sp.) were the non-commercial species that was most often mistaken for a commercial species in our study area.

We could detect no effect of the fishery on the size structure of the commercial sponges that we monitored. The mean diameter of glove sponges $(11.1 \mathrm{~cm})$, yellow sponges $(11.1 \mathrm{~cm})$, and wool sponges $(13.8 \mathrm{~cm})$ before and after the four-month peak fishing season differed by $\sim 2 \%$. The rate of sponge loss also did not differ significantly between our marked (i.e., marked with a research buoy) and un-marked sites in the four regions we studied (two sample t-test; $t=0.962$, $\mathrm{df}=6 ; \mathrm{P}=0.67)$, an indication that fishers did not specifically target, nor avoid areas that we had marked with research buoys.

We received 106 daily logbook records completed by captains on four "mother ship" fishing vessels that operate with multiple fishers each in separate small dinghies. Vessels reported deploying a mean of three fishing dinghies each day (sd: 1.9; range: 0 - 8), yielding a mean daily sponge harvest of 255 sponges per vessel (sd: 128; range: 93 - 830). The bycatch reported by fishermen of sublegal commercial species and non-commercial species was $1.3 \%$ and $1.8 \%$ (respectively) of their daily total sponge harvest, or about 3 - 5 erroneously harvested sponges per day. This is on par with our diver-based estimates of the bycatch of sublegal sponges (3.5\% of population per mo) and non-commercial sponges ( $4.3 \%$ of population per mo). During the peak of the fishing season, fishermen reported fishing on 66 days ( $\sim 50 \%$ of the available days $)$ and fished for an average of $6.5 \mathrm{hrs} / \mathrm{d}$ (sd: 1.2; range: 3 - $9 \mathrm{hrs).} \mathrm{As} \mathrm{noted} \mathrm{earlier,} \mathrm{the} \mathrm{sponge}$ fishing season in the Florida Keys is focused during the summer months (June - Sept) when winds are generally at their lowest (Fig. 3a). Within this time-frame, fishermen tend to harvest sponges during periods when winds are low $(<10 \mathrm{kts})$, as documented by comparing logbook data completed by fishermen with meteorological data for Key West (NOAA - National Weather Service; http://www.srh.noaa.gov/key/?n=climate) during the summer of 2003 (Fig. 3b).

\subsection{Growth, mortality, and reproduction}

A total of 208 sponges from four commercially valuable species (wool sponge, yellow sponge, glove sponge, grass sponge) were monitored to estimate growth (i.e., change in diameter), which varied significantly among species $(\mathrm{F}=4.754$, $\mathrm{df}=3,208 ; \mathrm{p}=0.003)$ and sampling periods $(\mathrm{F}=5.178, \mathrm{df}=1,208 ; \mathrm{p}=0.024)$. There was also a significant interaction between sampling period and species on sponge growth $(\mathrm{F}=3.655$; $\mathrm{df}=3,208 ; \mathrm{p}=0.013)$. Growth was greater for three species (yellow sponge, glove sponge, grass sponge) during the fall sampling, whereas the growth of wool sponges was greater in the spring sampling period (Fig. 4). On average, sponges grew approximately $0.2 \mathrm{~cm}$ in diameter per month.

Based on the disappearance of sponges on undisturbed study sites study (1.9\% per mo) and at unfished sites where we monitored sponge growth (1.0\% per mo), we estimate natural mortality of sponges to be $\sim 1-2 \%$ per mo. Among commercial sponges, glove sponges and yellow sponges had similar rates of disappearance $(\sim 2 \%$ per mo). We did not detect the disappearance of any wool sponges on sites that appeared unfished.

Gametocytes were detected in only 33 of the 119 sponges sampled for reproductive analysis during the study: $8 \%$ of the glove sponges, $38 \%$ of the grass sponges, $13 \%$ of the wool sponges, and $27 \%$ of the yellow sponges that we sampled in July were reproductive (Fig. 4). The number of gametocytes in tissue samples from yellow sponges, glove sponges, and wool sponges were positively and significantly related to sponge size, whether measured as sponge volume $(\mathrm{F}=$ $\left.4.762 ; \mathrm{df}=1,15 ; \mathrm{P}=0.047 ; \mathrm{r}^{2}=0.254\right)$ or diameter $\left(\mathrm{F}=9.270 ; \mathrm{df}=1,15 ; \mathrm{P}=0.009 ; \mathrm{r}^{2}=\right.$ 0.398 ) yet, both relationships explained $<40 \%$ of the variance in gametocyte number. There 
was no relationship between sponge size (diameter or volume) and proportion of reproductive tissue in grass sponges (Fig. 5). There was also no significant relationship between the total area of reproductive tissue found in sponges and sponge diameter $\left(\mathrm{F}=0.169 ; \mathrm{df}=15 ; \mathrm{P}=0.688 ; \mathrm{r}^{2}=\right.$ $0.012)$ or volume $\left(\mathrm{F}=0.500 ; \mathrm{df}=1,15 ; \mathrm{P}=0.491 ; \mathrm{r}^{2}=0.034\right)$. Sponges containing both oocytes and spermatocytes typically had more gametocytes $\mathrm{mm}^{-2}$ than those containing just a single type of gametic tissue.

\subsection{Reattachment experiment}

The probability of reattachment of roller sponges in the tethering experiment varied among sponge species and between locations. At both sites, wool sponges reattached most readily (33\% in $6 \mathrm{mo}$ ), whereas only a few glove sponges reattached after 18 mos (Fig. 6). Rates of reattachment were also higher on the site with a thinner sediment depth and presumably better access to bedrock on which the sponges could reattach. Mortality of the tethered roller sponges was in the range of $0-5 \%$ per mo depending on the species, which was similar to the natural mortality $(\sim 2.5 \%)$ estimated for attached sponges (Fig. 7 ; top panel). All of the yellow and glove sponge rollers survived our 18 mo tethering study, whereas $30 \%$ of the wool sponges died. Results from the tethering experiment also revealed that rollers generally grew at rates comparable to naturally attached sponges $(\mathrm{F}=1.033 ; \mathrm{df}=1,228 ; \mathrm{P}=0.311)$, with the exception of the wool sponges that actually grew faster as rollers as compared to individuals that were attached $(\mathrm{F}=5.768 ; \mathrm{df}=2,228 ; \mathrm{P}=0.004)$ (Fig. 7; bottom panel).

\section{Discussion}

The harvest of natural sponges in the Florida Keys, a booming industry prior to World War II, now only supports a small fishery both in terms of the number of active fishers and the quantity of sponges removed from the seafloor. Nonetheless, it is a controversial fishery because of public concern about the impact of sponge harvest on the marine ecosystem within the Florida Keys National Marine Sanctuary. Our study revealed that the sponge fishers working within our study areas were in compliance with fishery size and gear regulations. The bycatch of undersized or undesirable sponges was also minimal and sponges released by fishers grew at rates comparable to attached sponges. Those "roller" sponges tended to remain in the area in which they were released and many reattached to the seafloor within a few months, although this varied among species and among sites that differed in sediment depth.

We found that harvest of legal-sized commercial sponges can be locally intense, especially in shallow water under calm conditions. However, the harvest is patchy in its distribution leaving approximately $40 \%$ of the shallow seafloor untouched in heavily fished areas during the primary fishing season. Moreover, because sponges are harvested by fishers working aboard small skiffs from the surface using hooks, an estimated $41 \%$ of those harvested leave sufficient tissue attached to the seafloor for sponge regrowth (Stevely, 1985). We estimate, based on the growth rates that we measured, that if sufficient tissue remains after harvesting then sponges may regrow to legal size in as few as five years. This rate varies among species and seasons, and will also depend on the degree of tissue damage incurred while harvesting, a facet of the fishery that we did not examine. Our estimates of regrowth are similar to estimates from previous studies of wool sponges in the same region, indicating that sponges could grow to legal size in 3 - 6 yrs (Moore, 1901 cited in Stevely et al., 1978; Smith, 1954; Storr, 1964). Taking all of these factors into account, we conclude that at the harvest rates we measured, the commercial sponge fishery has a negligible impact on the sponge community in the Florida Keys, only a fraction of which are commercial sponges. 
Instead, the greatest threat to sponges in the Florida Keys is not the sponge fishery but changes in water quality, especially the reoccurrence of harmful algal blooms (HAB) created by the cyanobacteria Synecochoccus sp. that at high concentrations is lethal to sponges (Butler et al., 1995; Herrnkind et al., 1997; Phlips and Badylak, 1996; Phlips et al., 1999). The causes of the HABs in Florida Bay are not completely understood or predictable (Briceño and Boyer, 2010; Goleski et al., 2010; Melesse et al. 2008), but appear to be sparked by a combination of unusual salinities and a pulse of a limiting nutrient (Blakely et al., 2015). The threat of HABS to sponge communities is clear. Surveys of sponge communities at many sites in Florida Bay before and after the 1991-92 bloom and the 2007 bloom revealed that $>90 \%$ of the sponges and sponge species were lost on sites exposed to HABs that for months blanketed an area $>500 \mathrm{~km}^{2}$ (Butler et al., 1995, 2015). Recovery of sponge communities after HABs has been slow or non-existent (Stevely et al., 2011), probably a consequence of their limited larval dispersal and slow growth. Surveys undertaken between 2001-2005, ten years or more after the initial HABs, still found total sponge abundances to be only $\sim 40 \%$ of their pre-HAB levels with no evidence of recruitment of the largest sponge species (Stevely and Sweat, 2002). So it appears that recovery of the sponge community from HABs by natural processes may require decades (Stevely et al., 2011). To date, the HABs have been limited to the middle and upper Florida Keys regions, sparing sponge communities in the lower Keys and areas west of Key West from the destruction they wreak. In contrast to the devastation of entire sponge communities by HABs, sponge fishers target $<10 \%$ of the sponge species in the region, only harvest the largest of those sponges, and their fishing methodology is inefficient and limited to shallow water areas outside of protected zones.

It is possible, however, that the reproductive potential (i.e., number of new recruits produced per yr) of commercial sponges may be compromised by locally intense fishing. Gamete production by three of the four sponge species we studied scaled positively with sponge size. The largest sponges that produce the most new recruits are also the most valuable, hence most likely to be harvested. Yet in the heavily fished areas that we studied, we did not detect a decline in the mean size of sponges as compared to areas subject to less fishing. Only a low proportion of sponges were reproductively active during our summer study period, so we obtained a much smaller data set on size-specific reproduction than desired. That is unfortunate because there is a lack of data on the patterns of reproduction and recruitment of shallow-water sponges (Kaye and Rieswig, 1991a,b; Maldonado and Riesgo, 2008), but understanding seasonal and annual variation in sponge reproductive success will require longer studies than ours. Previous studies of sponge growth in the Caribbean have relied upon a $1-3$ yr sampling frame (Moore, 1910; Crawshay, 1939; Storr, 1964; Cropper and DiResta, 1999), but a thorough analysis of sponge reproductive patterns will probably require an even longer time-series of data.

The rates of sponge removal by fishers that we determined are not equivalent to traditional measures of fishing mortality. First, our study was conducted during the peak harvest season and did not include many months when harvest is negligible due to higher winds, so our estimates probably represent the upper limit of monthly harvest levels. Second, even during the peak harvest season, we estimate that as much as $40 \%$ of the sponge-dominated hard-bottom areas were not visited by fishers. Fishers tend to revisit sites on an irregular timescale, but their haphazard movement through the fishing grounds and inefficient harvesting of sponges when water visibility is poor or their vision obscured (e.g., when there are dense aggregations of octocorals or macroalgae, high winds, high cloud cover, etc.) means that many legal sponges in an area are left untouched. In fact, several fishers that we interviewed believed that sponges grow 
to legal size in less than a year, because they think that they harvest nearly all the legal sponges in a given area but find more legal sponges when they return to the same site less than a year later. Our results and those of others (Moore, 1910; Crawshay, 1939; Storr, 1964; Cropper and DiResta, 1999) indicate that sponges do not grow that fast, and fishers are simply finding sponges that they previously overlooked.

Perhaps the most important reason that the rates of sponge removal that we determined are not equivalent to traditional measures of fishing mortality is due the peculiar nature of sponge fisheries: most harvested sponges are not killed - they regrow from tissue that remains on the seafloor (Stevely, 1985). Studies show that cutting sponges from the seafloor as a harvesting technique results in survival rates from the remaining tissue of $71 \%$ as compared to $41 \%$ for sponges that are torn from the seafloor by fishers using hooks, as is the practice in the Florida Keys (Stevely, 1985). In addition, our results show that sublegal and non-commercial sponges released as "rollers" experience low mortality, grow at rates similar to uncut sponges, and often reattach to the substrate so they can be reharvested later once after they reach legal size. So when fishers erroneously harvest but then discard sublegal or non-target sponges from the bottom, many will survive and will become available for future harvest.

\section{Conclusions}

Our results suggest that the current rates of harvest by the sponge fishery in the Florida Keys is likely to be sustainable and the fishery's impact in terms of bycatch on the non-commercial sponge community is negligible. However, additional data on sponge reproductive patterns and recruitment success are needed to empirically parameterize population models capable of quantitatively assessing the sustainability of current harvest levels. Such models will also need to include the spatially patchy, inefficient dynamics of sponge harvest and the unusual biological characteristics of sponges, including: both positive and negative growth trajectories dependent on environmental conditions; the regrowth of harvested sponges if sufficient tissue remains behind on the seafloor; and the fishery-induced presence of rollers along with their movement, reattachment, survival, and reproduction. Although our findings are encouraging and imply that sponge fishing is likely to be sustainable at current levels of intensity, we are reminded that current fishery regulations are minimal, have no known basis in sponge biology, and are not supported by the monitoring or assessment of commercial sponge stocks. Those management measures are necessary to truly understand the impact of the commercial harvest of sponges on sponge communities in the Florida Keys and to preserve the unique, artisanal fishery for these enigmatic animals.

\section{Acknowledgements}

We appreciate the field and laboratory assistance of Scott Donahue, Jennifer Lear, Jason Goldstein, Peter Bouwma, David Cook, and Monica McGarrity - all former students or technicians at Old Dominion University. Reviews of earlier versions of the manuscript by Emily Anderson, Gayathiri Gnanalingam, and Jason Spadaro greatly improved the document. Funding for this project was provided by a NOAA Center for Sponsored Coastal Ocean Research/Coastal Ocean Program (CSCOR/COP) grant to M. Butler (NA16OP2561).

\section{References}

Behringer, D.C., and Butler, IV M.J., 2006. Stable isotope analysis of production and trophic relationships in a tropical marine hard-bottom community. Oecologia 148: 334-341. 
Bell, J.J., 2008. The functional roles of marine sponges. Estuar. Coast. Shelf Sci. 79: 341-353.

400

401

402

403

404

405

406

407

408

409

410

411

412

413

414

415

416

417

418

419

420

421

422

423

424

425

426

427

428

429

430

431

432

433

434

435

436

437
Blakey, T., Melesse, A.M., and Rousseaux, C.S., 2015. Toward connecting subtropical algal blooms to freshwater nutrient sources using a long-term, spatially distributed, in situ chlorophyll-a record. Catena 133: 119-127.

Boyer, J.N., Fourqurean, J.W., and Jones R.D., 1997. Spatial characteristics of water quality in Florida Bay and Whitewater Bay by multivariate analyses: zones of similar influence. Estuaries 20: 743-758.

Briceño, H.O., and Boyer J.N. 2010. Climatic controls on phytoplankton biomass in a subtropical estuary, Florida Bay, USA. Estuar. Coast. 33: 541-553.

Brito, D., 2008. Amphibian conservation: Are we on the right track? Biol. Conserv. 141: 29122917.

Butler IV, M.J., Hunt, J.H., Herrnkind, W.F., Childress, M.J., Bertelsen, R., Sharp, W., Matthews, T., Field, J.M. and Marshall H.G., 1995. Cascading disturbances in Florida Bay, USA: implications for juvenile spiny lobsters Panulirus argus. Mar. Ecol. Prog. Ser. 129: 119-125.

Butler, M.J. IV, Herrnkind, W.F, and Hunt, J.H., 1997. Factors affecting the recruitment of juvenile Caribbean spiny lobsters dwelling in macroalgae. Bull. Mar. Sci. 61:3-19

Butler, M.J. IV, Dolan, T., Herrnkind, W.F., and Hunt, J.H., 2001. Modeling the effect of spatial variation in postlarval supply and habitat structure on recruitment of Caribbean spiny lobster. Mar. Freshwater. Res. 52: 1243 - 1253

Butler, M.J. IV, Behringer, D.C. Jr., Dolan T.W. III, Moss J., and Shields, J.D., 2015. Behavioral Immunity Suppresses an Epizootic in Caribbean Spiny Lobsters. PLoS ONE 10(6): e0126374.

Chiappone, M. and Sullivan, K.M., 1994a. Ecological structure and dynamics of nearshore hardbottom communties in the Florida Keys. Bull. Mar. Sci. 54: 747-756

Chiappone, M. and Sullivan, K.M., 1994b. Patterns of coral abundance defining nearshore hardbottom communties of the Florida Keys. Florida Sci. 57: 108-125

Chiappone, M.,1996. Marine benthic communities of the Florida Keys, Vol. 4 of Site Characterization for the Florida Keys National Marine Sanctuary and Environs, Farley Court Pub., Zenda, Wisconsin.

Crawshay, L.R., 1939. Studies in the market sponges. 1. Growth from the planted cutting. J. Mar. Biol. Assn. UK 23: 553-574.

Cropper, W.P. Jr. and DiResta, D., 1999. Simulation of a Biscayne Bay, Florida commercial sponge population: effects of harvesting after Hurricane Andrew. Ecol. Model. 118: 2 - 15.

Diaz, M.C. and Ward, B.B., 1997. Sponge-mediated nitrification in tropical benthic communities. Mar. Ecol. Prog. Ser. 156: 97-107.

Duffy, J.E., 2002. The ecology and evolution of eusociality in sponge-dwelling shrimp. pp 1-38, In: Genes, Behavior, and Evolution in Social Insects. Kikuchi, T. (editor). University of Hokkaido Press, Sapporo, Japan. 
Fell, P.E., 1983. Oogenisis, oviposition, and oosorption, pp. 1-29 in Reproductive Biology of Invertebrates Vol. 1 , K.B. and R.G. Adiyodi (eds.), J. Wiley \& Sons Pub., Chichester, England.

Fiore, C.L., D.M. Baker \& M.P. Lesser. 2013. Nitrogen biogeochemistry in the Caribbean sponge, Xestospongia muta: A source or sink of dissolved inorganic nitrogen? PLoS One 8: e72961

Fourqurean, J.W. and Robblee, M.B., 1999. Florida Bay: a history of recent ecological changes. Estuaries 22(2B): 345-357.

Goleski, J., Koch, F., Marcoval, M., Wall, C., Jochem, F., Peterson, B., and Gobler, C. J., 2010. The role of zooplankton grazing and nutrient loading in the occurrence of harmful cyanobacterial blooms in Florida Bay, USA. Estuar. Coast. 33:1202-1215.

Herrnkind, W.F., Butler IV, M.J., Hunt, J. and Childress M., 1997. The role of physical refugia: implications from a mass sponge die-off in a lobster nursery. Mar. Freshwat. Res. 48: 759770

Hughes, T. P., 1994. Catastrophes, phase shifts, and large-scale degradation of a Caribbean coral reef. Science 265(5178): 1547-1551.

Jackson, J. B., Kirby, M. X., Berger, W. H., Bjorndal, K. A., Botsford, L. W., Bourque, B. J., Bradbury, R.H., Cooke, R., Erlandson, J., Estes, J., Hughes, T.P., Kidwell, S.D., Lange, C.B., Lenihan, H.S., Pandolfi, J.M., Peterson, C.H., Steneck, R.S., Tegner, M.J., Warner, R.R. 2001. Historical overfishing and the recent collapse of coastal ecosystems. Science 293(5530): 629-637.

Karr, J.R., 1992. Ecological integrity: Protecting earth's life support systems. Ecosystem health-new goals for environmental management, Island Press, Washington, DC: 223-238.

Kaye, H.R. and Reiswig H.M., 1991a. Sexual reproduction in four Caribbean commercial sponges. I. Reproductive cycles and spermatogenesis. Invert. Reprod. Develop 19: 1-11.

Kaye, H.R. and Reiswig H.M., 1991b. Sexual reproduction in four Caribbean commercial sponges. III. Larval behaviour, settlement and metamorphosis. Invert. Reprod. Develop.19: 25-35.

Lynch, T.C. and Phlips, E.J., 2000. Filtration of the bloom-forming cyanobacteria Synechococcus by three sponge species from Florida Bay, USA. Bull. Mar. Sci. 67:9231213.

Maldonado, M., 2006. The ecology of sponge larvae. Canadian Journal Zoology 84:175-194.

Maldonado, M. and Riesgo C., 2008. Reproduction in the Phylum Porifera: a synoptic overview. Treballs de la SCB 59: 29-49.

Melesse, A.M., Krishnaswamy, J., and Keqi, Z., 2008. Modeling Coastal Eutrophication at Florida Bay using Neural Networks. J Coast. Res. 24: 190-196.

Moore, H.F., 1910. The commercial sponges and the sponge fisheries. Bull. US Fish Comm. Part I, 28: 399-511.

Newell, R.I.E., 1988. Ecological changes in Chesapeake Bay: Are they the result of overharvesting the American oyster, Crassostrea virginica. Adv. Chesap. Bay Res. 129: 536546. 
Pawlik, J.R., Loh, T.L., McMurray, S.E., and Finelli, C.M., 2013. Sponge communities on Caribbean coral reefs are structured by factors that are top-down, not bottom-up. PLoS ONE 8(5):e62573

Peterson, B.J., Chester, C.M., Jochem, F.J., and Fourqurean, J.W., 2006. Potential role of sponge communities in controlling phytoplankton blooms in Florida Bay. Mar. Ecol. Prog. Ser. 328: 93-103.

Phlips, E.J. and Badylak, S., 1996. Spatial distribution and composition of algal blooms in Florida Bay. Bull. Mar. Sci. 58: 203-216.

Phlips, E.J., Badylak, S., and. Lynch, T.C., 1999. Blooms of the picoplanktonic cyanobacterium Synechococcus in Florida Bay, a subtropical inner-shelf lagoon. Limnol. Oceanog. 44: 11661175.

Rathbun, R., 1887. The sponge fishery and trade. In George Brown Goode, The fisheries and fishery industries of the United States, 5(2): 817-841.

Reiswig, H.M., 1983. Spermatogensis and sperm function, pp. 1-21 in Reproductive Biology of Invertebrates Vol. 2 , K.B. and R.G. Adiyodi (eds.), J. Wiley \& Sons Pub., Chichester, England.

Schomer, N.S. and Drew, R.D., 1982. An ecological characterization of the Lower Everglades, Florida Bay, and the Florida Keys. U.S. Fish \& Wildlife Service, Washington D.C., FWX/OBS-82-58.1, 246p.

Simpson, T.L., 1984. The Cell Biology of Sponges, Springer-Verlag, New York, NY.

Smith, F. G., 1954. Biology of the commercial sponge. Fish. Bull. Fish Wildl. Ser. 89: 263-266

Slattery, M., Gochfeld, D.J., Easson, C.G. and. O’Donohue, L.R.K. 2013. Facilitation of coral reef biodiversity and health by cave sponge communities. Mar. Ecol. Prog. Ser. 476: 71-86

Southwell, M.W., Weisz, J.B., Martens, C.S., and Lindquist, N.. 2008. In situ fluxes of dissolved inorganic nitrogen from the sponge community on Conch Reef, Key Largo, Florida. Limnol. Oceanog. 53: 986-996

Stevely, J.M., Thompson, J.C., and Warner R.E., 1978. The biology and utilization of Florida's commercial sponges. Florida Sea Grant Techincal Paper No. 8, Gainesville, Florida, USA, 49pp.

Stevely, J.M., 1985. Survival and growth of cut versus hooked commercial sponges. Florida Sea Grant Technical Paper No. 38, Gainesville, Florida, USA, 12pp.

Stevely, J.M. and Sweat, D.E., 2008. Exploring the potential and protecting the resource: Florida's marine sponges. Florida Sea Grant Technical Paper No. 169, Gainesville, Florida, USA, 4pp.

Stevely J.M., Sweat, D.E., Bert, T.M., Sim-Smith, C. and Kelly, M., 2008. Commercial Bath Sponge (Spongia and Hippospongia) and Total Sponge Community Abundance and Biomass Estimates in the Florida Middle and Upper Keys, USA. Proc. Gulf Caribb. Fish. Inst. 63: 384-400.

Stevely, J.M., Sweat, D., Bert, T.M., Sim-Smith, C. and Kelly, M., 2010. Commercial bath sponge (Spongia and Hippospongia) and total sponge community abundance and biomass 
estimates in the Florida middle and upper Keys, USA. Proc. Gulf Carib. Fish. Inst. 62: 394403.

522 Stevely, J.M., Sweat, D.E., Bert, T.M., Sim-Smith, C., and Kelly, M., 2011. Sponge Mortality at 523 Marathon and Long Key, Florida: Patterns of Species Response and Population Recovery. 524 Proc. Gulf Caribb. Fish. Inst. 63: 384-400.

525 Strickland, R. and Grosse, D.J., 2000. Fisheries, habitat, and pollution. Ecol. Appl. 10: 323-324.

526 Storr, J.F.,1964. Ecology of the Gulf of Mexico commercial sponges and tis relation to the fishery. U.S. Fish and Wildlife Service. Special Science Report 466: 73.

Torres, R.C., Butler, M.J., and Shellito, B., 2006. A GIS-based characterization of commercial sponge populations in the Florida Keys, FL (USA). Proc. Gulf Caribb. Fish. Inst. 57: 10431044.

Wall, C.C., Rodgers, B.S., Gobler, C.J., and Peterson, B.J., 2012. Responses of loggerhead sponges Spechiospongia vesparium during harmful cyanobacterial blooms in a sub-tropical lagoon. Mar. Ecol. Prog. Ser. 451: 31-43,

534 Witzell, W.N., 1999. The origin of the Florida sponge fishery. Quarterly Publication of the Key West Maritime Historical Society 9: 4.

Westinga, E. and Hoetjes P.C., 1981. The intrasponge fauna of Speciospongia vesparia (Porifera, Demospongiae) at Curaçao and Bonaire. Mar. Biol. 62:139-150. 


\section{List of Figures}

Figure 1: (Inset) Map of Florida (USA) with a rectangle indicating our study area in the Florida Keys. Study sites of different types are shown on the larger map of the Florida Keys. The hatched rectangles depict the four regions where we conducted our sponge fishery studies, from left to right those area are: the Lakes region west of Key West, Boca Chica Key (Lower Keys), Waltz Key (Lower Keys), and Duck Key (Middle Keys). The precise location of the 32 study sites within those four regions ( $\mathrm{n}=8$ sites per region) are not indicated as they were close together. Our sponge growth and reproduction studies were conducted on sponges at the locations indicated by circles, whereas our tethering study sites are shown by triangles.

Figure 2: Estimates of natural mortality and fishing mortality of the three most common commercial sponges (wool, yellow, glove) at our study sites, based on repeated observations of the number of individual sponges missing per month on sites with and without fishing activity.

Figure 3: (top) Average wind speed (mph) per month from 1981 - 2010 in our study area based on meterological data for Key West, FL (USA) from the NOAA - National Weather Service. (Photo inset): a typical sponge fisher and fishing technique in the Florida Keys (Photo courtesy of John Stevely). (bottom). Plot of average wind speed per day (mph; black line) during our study of sponge fishing activities from July - October 2003. Grey bars indicate time spans when fishermen reported being on the water and fishing for sponges.

Figure 4: Plot of sponge growth by sponge species and season. The centerline of each bar is the mean, the top and bottom of the bars are 95\% confidence intervals, and the error bar extensions depict the range of the data. Samples sizes for each measurement are shown above each data set.

Figure 5: (top plate) Example micrograph of a prepared tissue sample from a wool sponge (Hippospongia lachne) showing two reproductive structures: a spermatic cyst and an oogenic cyst). (bottom) Four plots showing the relationship between sponge volume and diameter ( $\mathrm{x}-$ axes) versus the number of gametocyte structures or the proportion of tissue area comprised of gametocyte tissue for four common species of commercial sponges: Glove, Grass, Wool, and Yellow.

Figure 6: Plot of the percentage of individual "roller" sponges of three species (Wool, Yellow, Glove) that reattached to the substrate over 18 months.

Figure 7: (top) Percent mortality over a four month study period of three species of sponge (Wool, Glove, Yellow) depending on whether they were attached to the substrate or unattached rollers. No mortality of yellow or glove sponges was observed. (bottom) The growth of the same three sponge species is plotted for attached, undisturbed sponges or unattached rollers. 

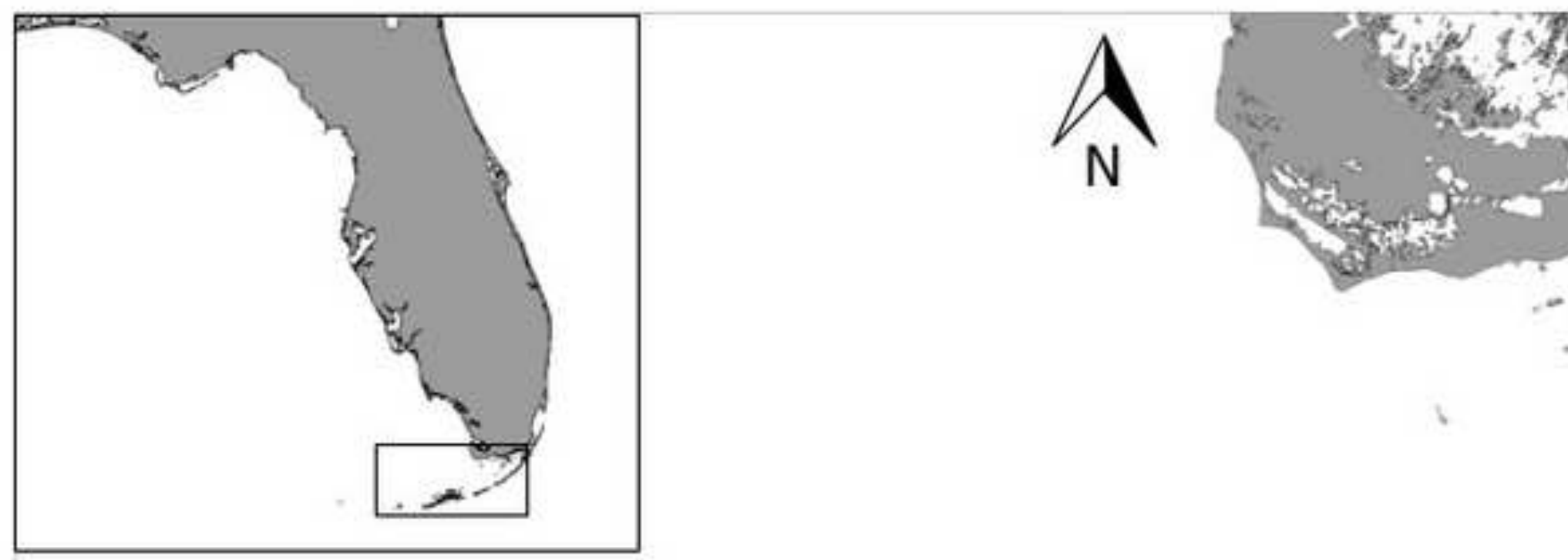

sis

A Tethering

- Growth and Reproduction

Region of Fishery Survey
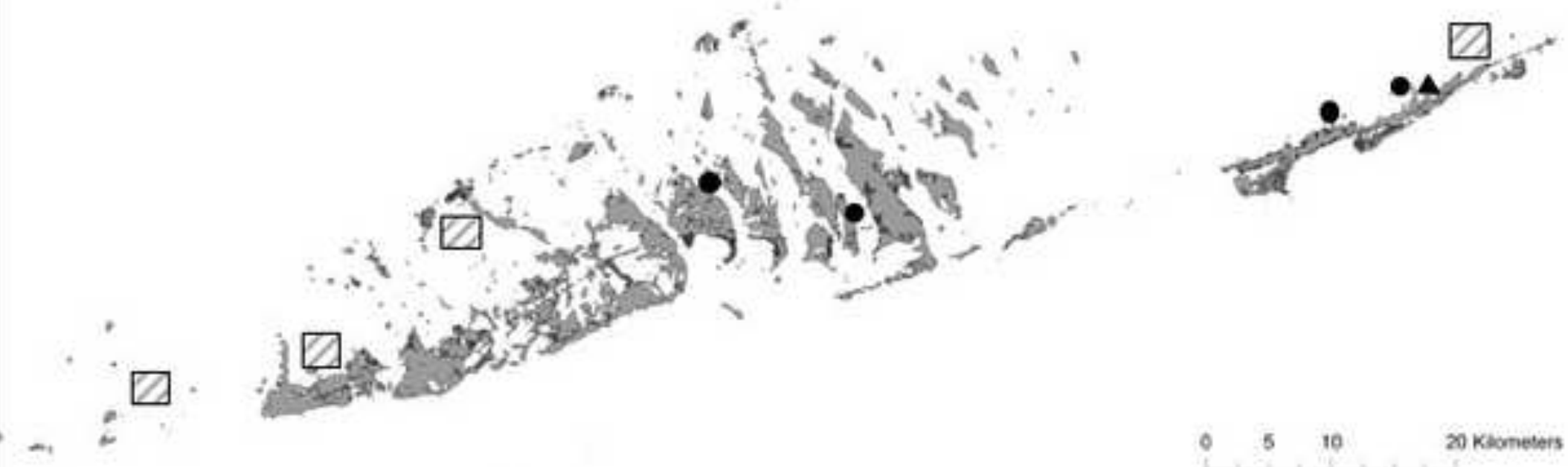

is,

- $510 \quad 20$ Koometers 


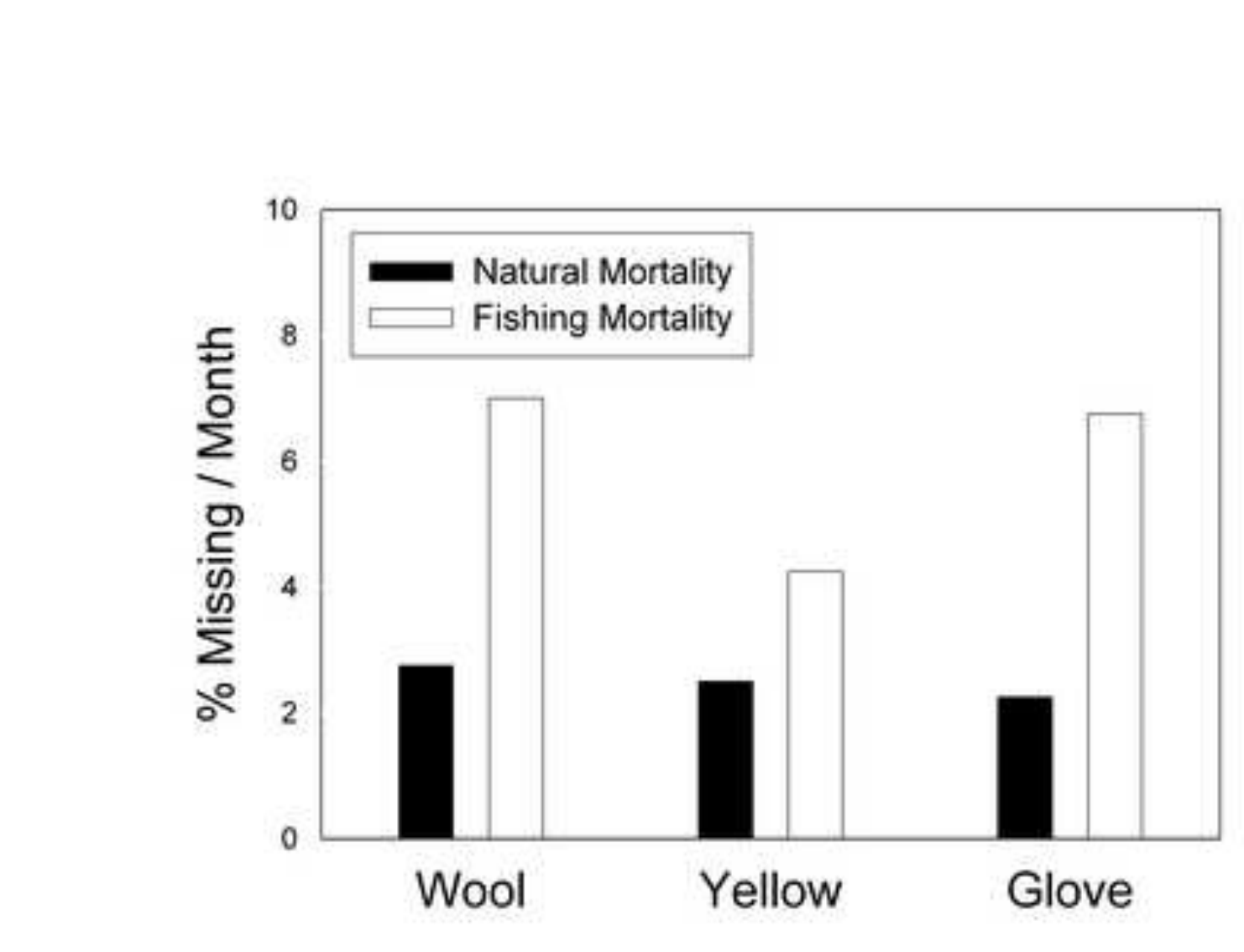

Figure 2

Fure 2

政

2

\section{(}
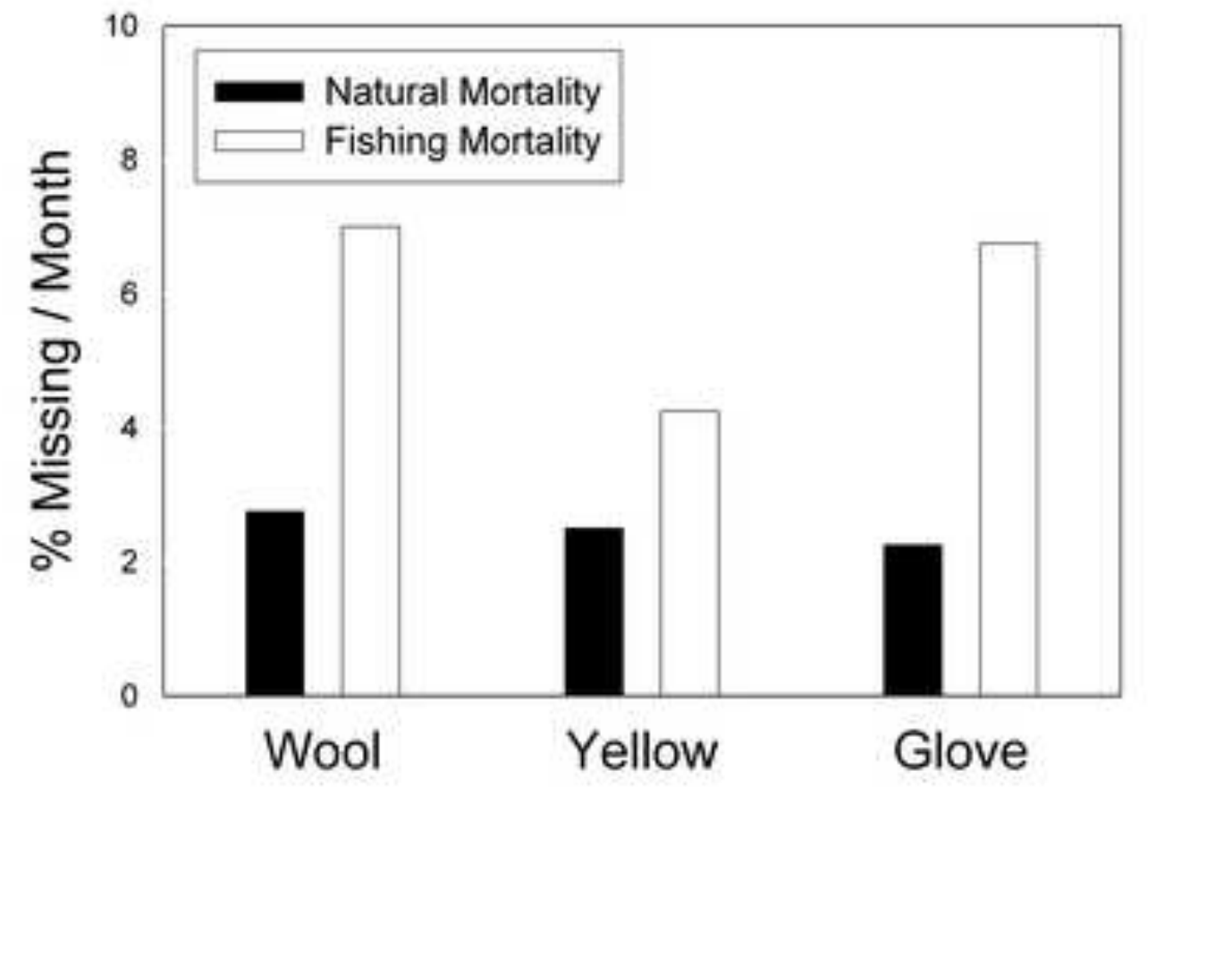

. 
Figure 3 revised
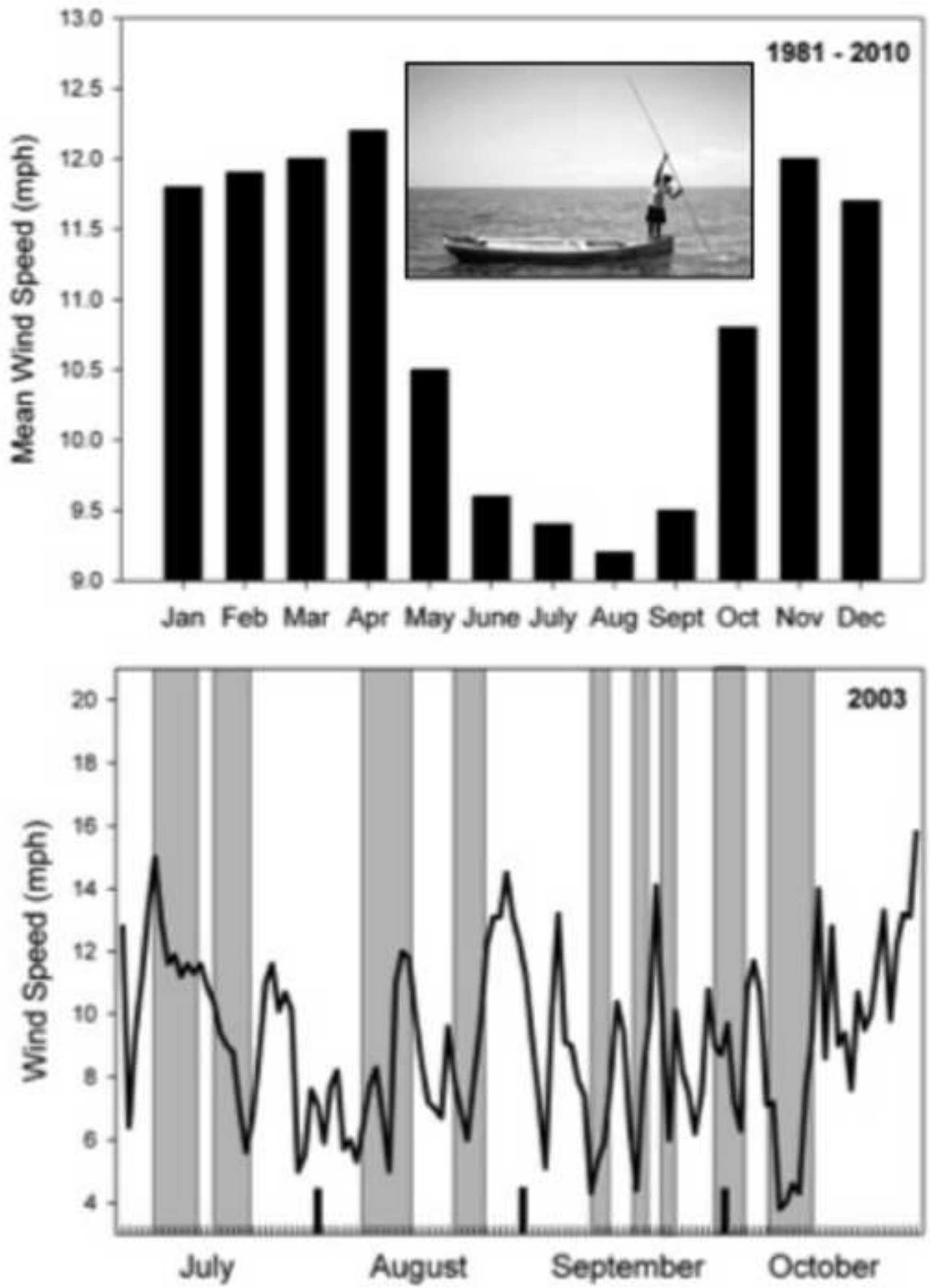

July August September October 


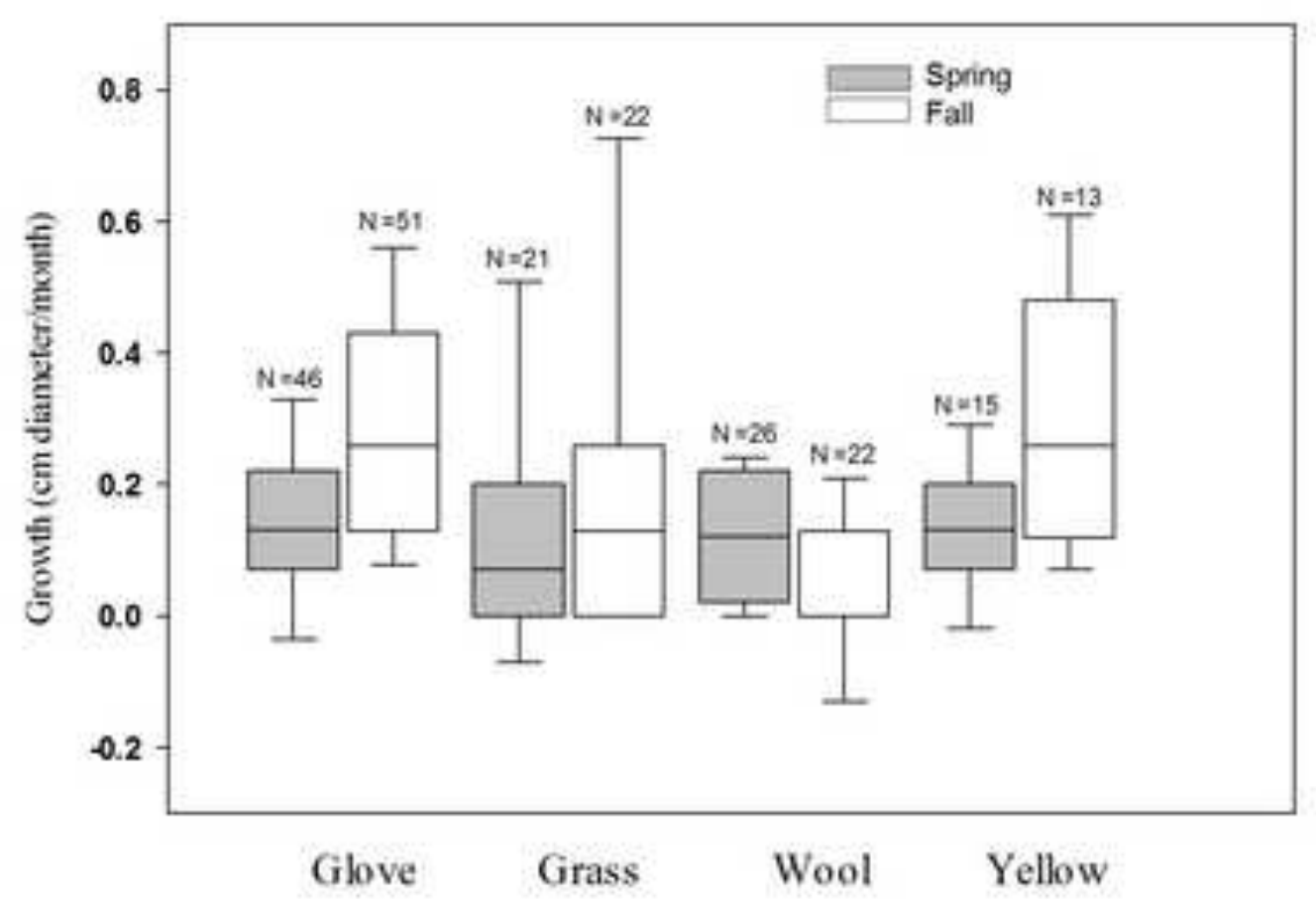

Figure 4 

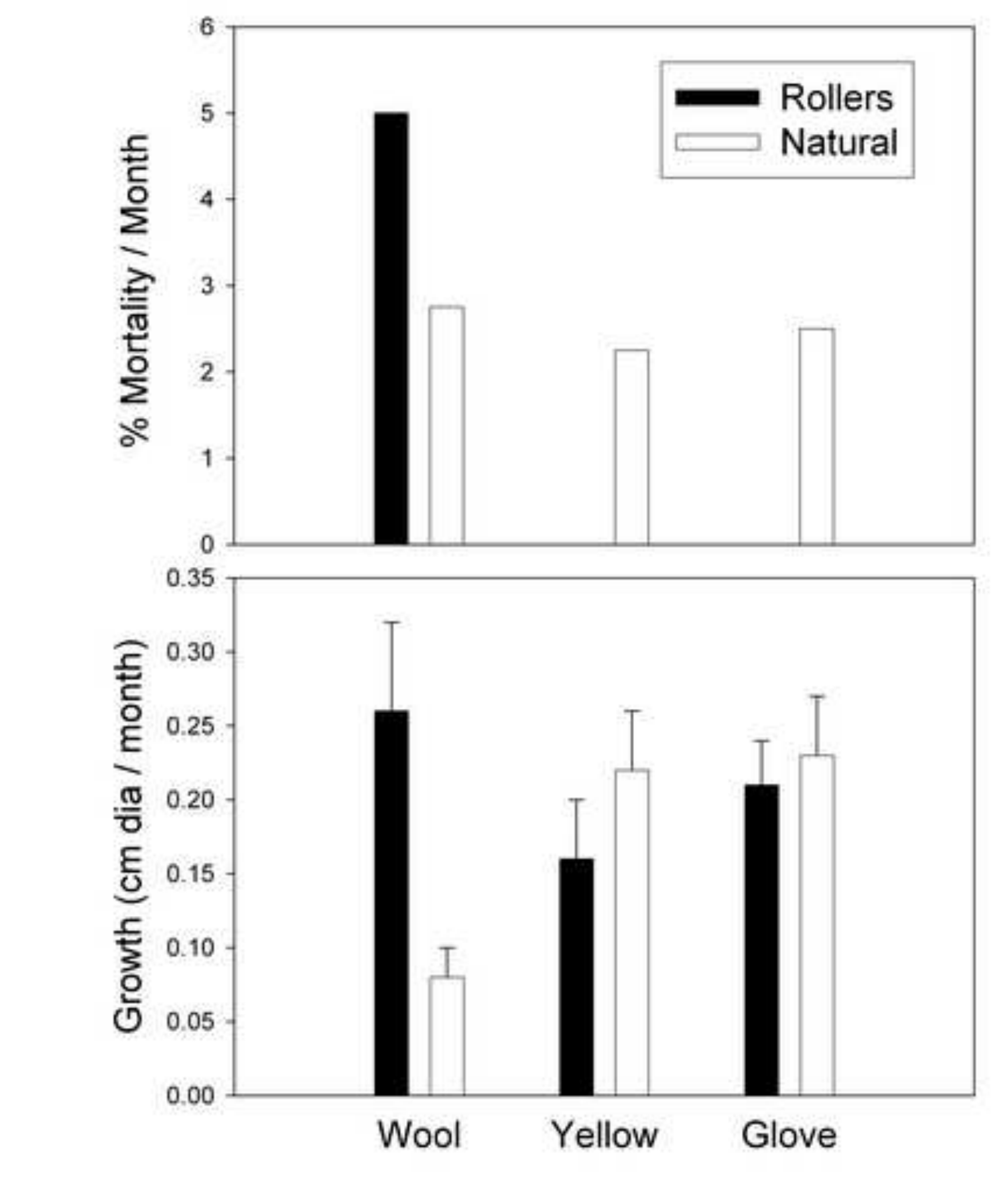

Figure 7

Figure 7

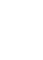

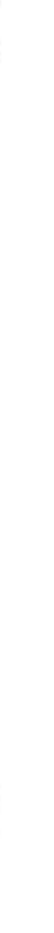

